\title{
Analysis of engineering geology conditions based on the quality of rock mass in the Tiga Dihaji Dam's diversion tunnel, South Sumatera, Indonesia
}

\author{
Zekrinaldi $^{1}$, Ferian Anggara ${ }^{1 *}$, and Hendy Setiawan ${ }^{1}$ \\ ${ }^{1}$ Gadjah Mada University, Sleman, Yogyakarta, Indonesia
}

\begin{abstract}
This research has examined the rock mass quality case study in the Tiga Dihaji Dam's diversion tunnel. Observations of geological conditions were carried out on the surface and subsurface of the study site and show that the study area consists of tuffaceous sandstone and carbonate interbeds. The method of this study is based on the classification of the Geological Strength Index (GSI), Rock Mass Rating (RMR), and the Q-system. The results indicate that tuffaceous sandstone has a GSI value of 15 - 87.5 (very poor very good), RMR 48 - 82 (fair - very good), and Q-system $0.01-60.0$ (exceptionally poor - very good). Meanwhile, carbonate interbeds have a low value, with a GSI value of 10.5 - 77.5 (very poor to very good), RMR 17.0 - 56.0 (very poor - fair), and Q-system 0 - 35.2 (exceptionally poor - good). Moreover, a correlation was made between rock mass quality for conditions in the study area. The correlation between GSI and RMR was obtained by the equation GSI $=2.2885 \mathrm{RMR}-82.567\left(\mathrm{R}^{2}=0.6653\right)$, RMR and Q-system $\mathrm{RMR}=2.0175 \ln (\mathrm{Q})+63.061\left(\mathrm{R}^{2}=0.4987\right)$, and GSI and Q-system GSI $=7.2119 \ln (\mathrm{Q})-54.578\left(\mathrm{R}^{2}=\right.$ $0.8095)$.
\end{abstract}

\section{Introduction}

The condition of the Selabung river during the rainy season has a large discharge. It even often becomes a problem both along the river channel and the surrounding areas. Meanwhile, in the dry season, the river flow has a slight discharge. The surrounding area becomes dry and causes water shortages in the agricultural area. For this reason, efforts were made to overcome this condition by constructing the Tiga Dihaji dam, which can be used as a reservoir for water during the rainy season.

The Tiga Dihaji Dam is located in the Selabung River, South Ogan Komering Ulu, South Sumatera, Indonesia (Figure 1). In constructing the Tiga Dihaji Dam, a diversion tunnel is needed to divert the flow of river water during the construction process. Based on the previous study [1], the diversion tunnel is on the right side of the river with approximately $595 \mathrm{~m}$ and a circular shape with a $7 \mathrm{~m}$ diameter. The elevation of the inlet tunnel is at $+221.0 \mathrm{~m}$ above sea level, while the outlet tunnel is located at $+218.41 \mathrm{~m}$ above sea level.

Appropriate techniques and technologies are required in the design and construction of a tunnel [2]. Geological detailed and engineering geology investigations on the surface and subsurface were carried out in the construction of this tunnel to determine the rock mass classification. The rock mass classification is an empirical method to identify the parameters that influence the behavior of these rocks and divides them into groups based on their characteristics [3]. The rock mass classifications analyzed in this study are Geological Strength Index [4], Rock Mass Rating [3], and Q-system [5].

Many previous researchers have published the correlation between the quality of rock mass (Table 1). However, none of the correlations can be used in general at specific locations due to the difference in geological conditions. So, it is necessary to correlate the quality of the rock mass, specifically at the study area.

Table 1. Correlation of rock mass quality by previous researchers.

\begin{tabular}{|c|c|c|}
\hline Authors & Empirical Correlation & Eq \\
\hline $\begin{array}{l}\text { Hoek and Brown } \\
\text { (1997) [6] }\end{array}$ & $G S I=R M R-5$ & (1) \\
\hline $\begin{array}{c}\text { Ali et al. (2014) } \\
\text { [7] }\end{array}$ & $\begin{array}{c}G S I=0.9932 R M R- \\
4.913\end{array}$ & (2) \\
\hline $\begin{array}{l}\text { Zhang et al. } \\
\text { (2019) [8] }\end{array}$ & $\begin{array}{c}R M R=0.827 G S I+ \\
15.394\end{array}$ & (3) \\
\hline $\begin{array}{c}\text { Bieniawski (1976) } \\
{[9]}\end{array}$ & $R M R=9 \ln (Q)+44$ & (4) \\
\hline $\begin{array}{c}\text { Cameron-Clarke } \\
\text { and Budavari } \\
(1981)[10]\end{array}$ & $R M R=5 \ln (Q)+60.8$ & (5) \\
\hline $\begin{array}{l}\text { Vásárhelyi and } \\
\text { Deák (2010) [11] }\end{array}$ & $R M R=7.10(Q)+68$ & (6) \\
\hline $\begin{array}{c}\text { Laderian and } \\
\text { Abaspoor (2012) } \\
{[12]}\end{array}$ & $\begin{array}{c}R M R=\underset{4.15 \ln (Q)+}{44.88}\end{array}$ & (7) \\
\hline
\end{tabular}

*Corresponding author: ferian@ugm.ac.id 


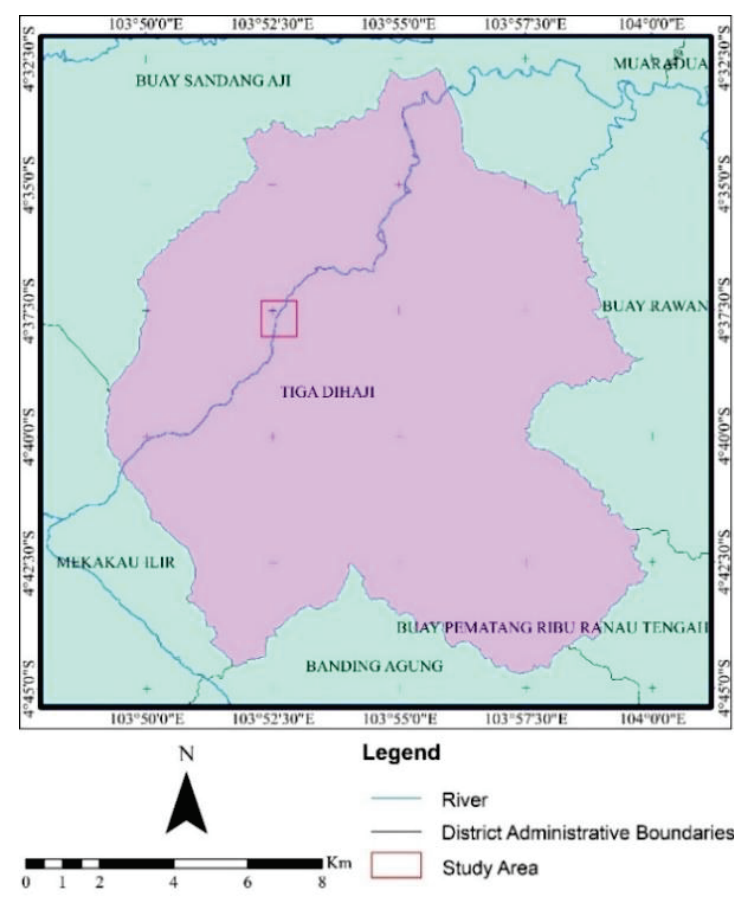

Fig. 1. Location map of the study area.

\section{Methodology}

\subsection{Geological conditions}

Observations of geological conditions were carried out on the surface and subsurface of the study site. Observations of surface geological conditions covering lithological conditions and geological structures and the results can be used as a reference for subsurface conditions. Meanwhile, observations under subsurface geological conditions are carried out on the drilling results in lithology and parameters in calculating rock mass quality.

In the study area, the rock mass quality analysis used subsurface data from the drilling results as many as three sample points, namely DIV-1 (tunnel inlet) with a depth of $65 \mathrm{~m}, \mathrm{DIV}-2$ (center of the tunnel) with a depth of 60 $\mathrm{m}$, and DIV-3 (tunnel outlet) a depth of $60 \mathrm{~m}$.

\subsection{RQD}

Deere initiated Rock Quality Designation (RQD) in 1963 [13]. RQD is a simple method for predicting rock mass quality obtained from drilling results and is considered rock mass. The RQD value is calculated by adding up the total length of the core pieces, which is more or equal to $10 \mathrm{~cm}$ to the total length of the core drilled (Figure 2). A good RQD value indicates the intact rock mass. The RQD value is used in determining the classification of other rock masses.

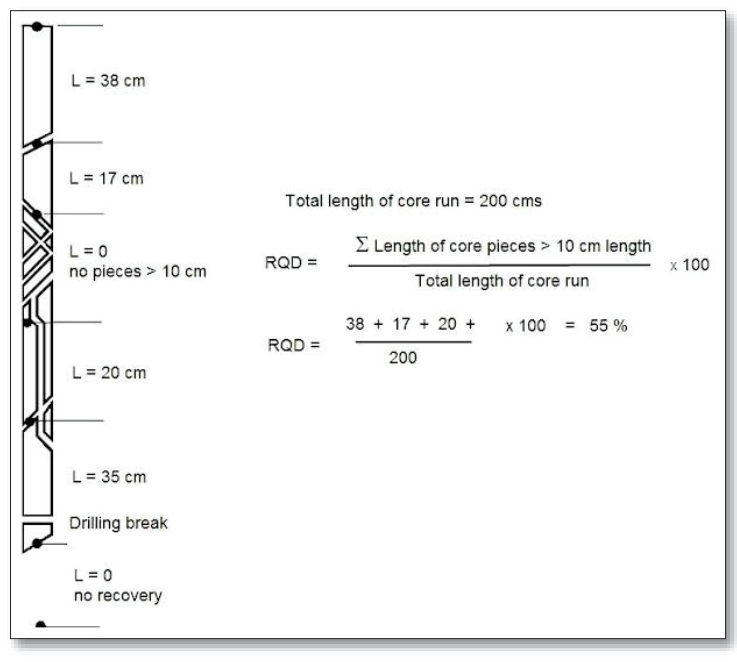

Fig. 2. Calculation of RQD value.

\section{$2.3 \mathrm{GSI}$}

The Geological Strength Index (GSI) is obtained from the joint condition value and the RQD value. The value of the joint condition refers to the classification of the joint condition [3]. The GSI calculation uses the following Equation 8 [4].

Where:

$$
G S I=1.5 J \text { cond }+R Q D / 2
$$

GSI = Geological Strength Index

Jcond $=$ Joint Condition

RQD = Rock Quality Designation

\subsection{RMR}

Rock Mass Rating (RMR) is a classification of rock mass using an empirical method in determining the assessment, which is used to evaluate the resistance of rock mass. Bieniawski classified rock mass from this method by summing up six parameters [3]. These parameters are rock strength, drill core quality, spacing of joints, conditions of joints, groundwater conditions, and discontinuity orientation. These parameters are obtained from subsurface observation data and laboratory results.

\subsection{Q-system}

The Rock Mass Quality (Q) System, also known as The Tunneling Quality Index, was first proposed Norwegian Geotechnical Institute (NGI). The Q-system is one of the classifications of rock masses based on a case study of more than 200 tunnels and caverns, mainly in Norway and Finland [5].

The Q-system is a function of the six parameters, which are stated in Equation 9.

$$
Q=\frac{R Q D}{J n} \times \frac{J r}{J a} \times \frac{J w}{S R F}
$$

Where:

$$
\text { RQD = Rock Quality Designation }
$$




$$
\begin{array}{ll}
\mathrm{Jn} & =\text { Joint set number } \\
\mathrm{Jr} & =\text { Joint roughness number } \\
\mathrm{Ja} & =\text { Joint alteration number } \\
\mathrm{JW} & =\text { Joint water reduction factor } \\
\mathrm{SRF} & =\text { Stress Reduction Factor }
\end{array}
$$

\subsection{Correlation between GSI, RMR, dan Q- system}

The results of the calculated rock mass quality are correlated through statistical analysis and regression equations. For the correlation representative, the coefficient of determination $\left(\mathrm{R}^{2}\right)$ is used to analyze the results obtained. The value of the coefficient of determination is in the range of 0 (zero) and 1 (one). If the coefficient of determination is close to 0 (zero), it means that the model's ability to explain the dependent variable is minimal. Meanwhile, suppose the value of the coefficient of determination of the variable is close to 1 (one). In that case, it means that the model's ability to explain the dependent variable is getting stronger.

\section{Results and discussion}

\subsection{Geological conditions}

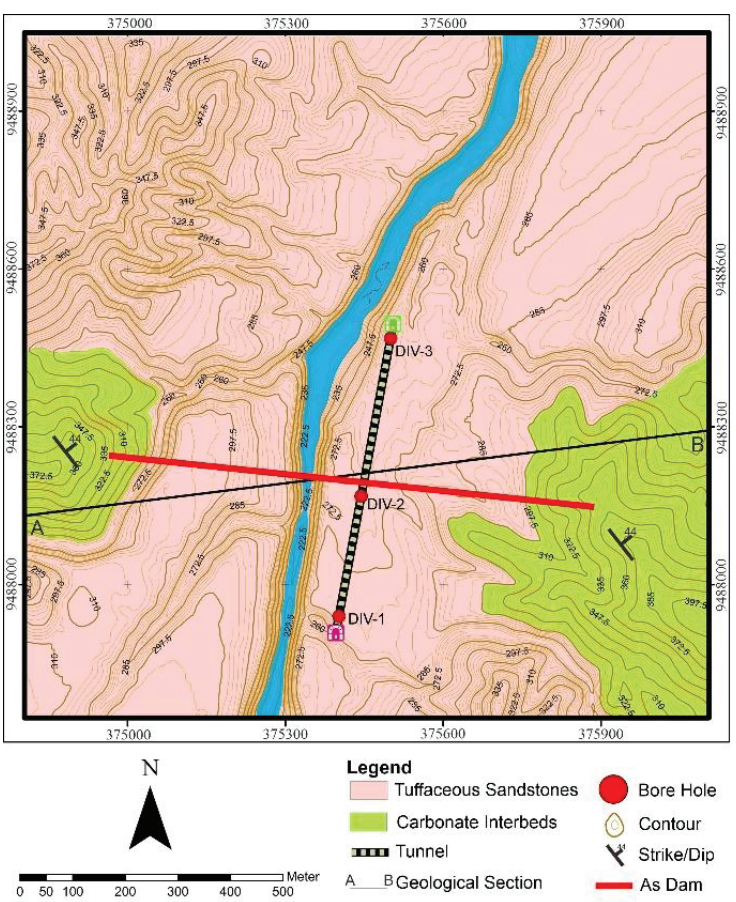

Fig. 3. Geological map of the study area.

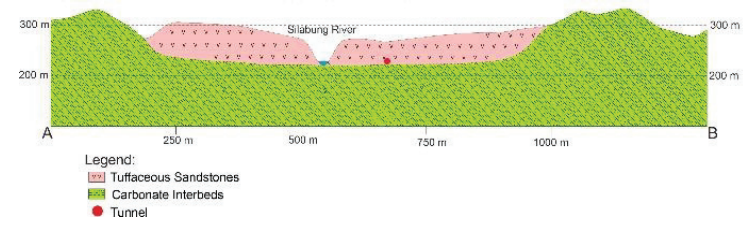

Fig. 4. Geological sections A - B.

According to the regional geology map of Indonesia on the Baturaja sheet [14], the regional geology of the study area is in the Ranau formation and the Gumai formation. The geological investigations show the tunnel is in the tuffaceous sandstone and carbonate interbeds, as shown in Figure 3 and Figure 4. In general, the tuffaceous sandstone is light grey to dark grey in color grain size of fine sand - medium sand, massive sedimentary structure, moderate sorting, packed closed, grain shape subrounded - subangular, low-level weathering, the minerals that make up the rock are still visible such as quartz, plagioclase, biotite, hornblende, and ash-sized materials, and weight of $\mathrm{\gamma}=1.4-2.2 \mathrm{gr} / \mathrm{m}^{3}$, triaxial $\mathrm{c}=$ $11.8-68.8 \mathrm{~kg} / \mathrm{cm}^{2} \phi=34.8^{0}-58.2^{0}$, uniaxial compressive strength $\sigma_{\mathrm{c}}=94.3-306.3 \mathrm{~kg} / \mathrm{cm}^{2}$.

Meanwhile, carbonate interbeds consist of carbonate sandstone, carbonate siltstone, and carbonate claystone with $3-30 \mathrm{~cm}$ of thickness and slope to the northeast $\left(\mathrm{N} 308^{\circ} \mathrm{E} / 44^{\circ}\right)$. This thin layer causes this rock to become brittle and also weak between the layering areas.

The core data analysis results show that the tunnel is between tuffaceous sandstone and carbonate interbeds (Figure 5).

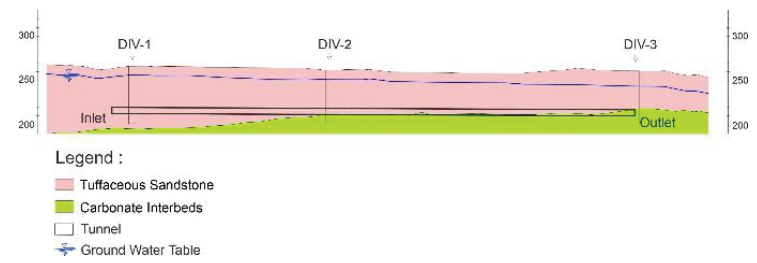

Fig. 5. Geological sections in the tunnel.

\subsection{RQD}

The RQD value of tuffaceous sandstone (Figure 6) obtained from this analysis ranges from $0-100$ or 76.35 average value, while the RQD of carbonate interbeds is between $0-80$ or with an average value of 15.37 (very poor quality). The average RQD value of the carbonate interbeds (Figure 7) is very bad due to its thin layers, which causes many cores to be lost during drilling activities.

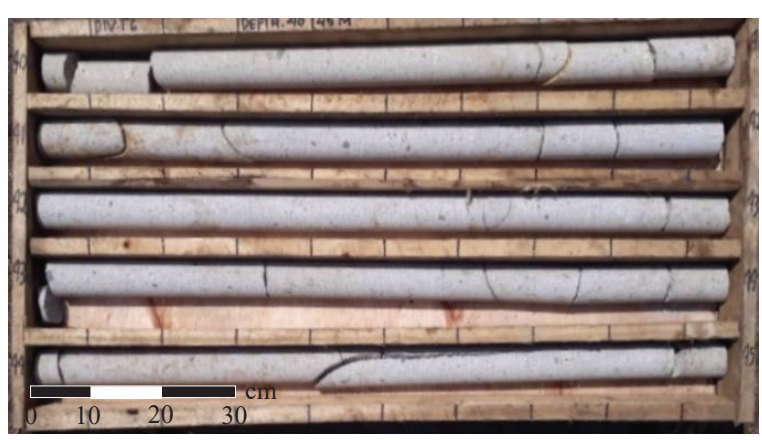

Fig. 6. Core example at DIV-1 (depth $40-45$ m).

\section{$3.3 \mathrm{GSI}$}

In the study area, the value of joint condition for tuffaceous sandstone has an average value of 25 . The joint surface is quite rough with cracks $<1 \mathrm{~mm}$, and the rocks are high to slightly weathered. The GSI value for 
tuffaceous sandstone is between $15-87.5$ or with an average value of 74.50 (good quality). Meanwhile, the joint condition of the carbonate interbeds has an average value of 7 , interpreted from surface geology due to the cores being destroyed (lost). The GSI values ranging from 10.5 to 77.5 , or the average is 26.16 (poor quality).

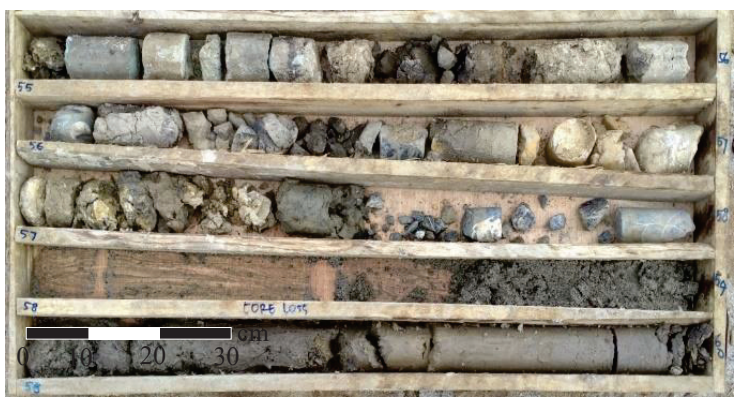

Fig. 7. Core example at DIV-2 (depth 55-60 m).

\subsection{RMR}

The RMR value for tuffaceous sandstone is 48.0 - 82.0, or an average of 68.63 (good quality), with UCS value rating is 2 , RQD rating is 17 , spacing of discontinuities rating is 20 , condition of discontinuities rating is 25 , and groundwater condition is 4 . Meanwhile, the RMR value of carbonate interbeds is 17.0 - 56.0 or an average of 26.22 (poor quality), with UCS value rating is 2 , RQD rating is 10 , spacing of discontinuities rating is 5 , condition of discontinuities rating is 10 , and groundwater condition is 4 .

\subsection{Q-system}

The analysis indicates that tuffaceous sandstone has a $\mathrm{Q}$ value between $0.01-60.0$ or an average value of 32.04 (good quality), while carbonate interbeds have a $Q$ value between 0.01 - 35.2 an average of 6.77 (medium quality).

As a comparison, the rock mass quality of each classification is attached in Table 2 .

Table 2. Summary of rock mass quality.

\begin{tabular}{|c|c|c|c|c|}
\hline \multirow{2}{*}{$\begin{array}{l}\text { Drill } \\
\text { point }\end{array}$} & \multirow{2}{*}{$\begin{array}{c}\text { Lithology } \\
\text { Unit }\end{array}$} & \multicolumn{3}{|c|}{ Average Value / Quality } \\
\hline & & GSI & RMR & Q-system \\
\hline DIV-1 & $\begin{array}{l}\text { Tuffaceous } \\
\text { sandstone }\end{array}$ & $\begin{array}{l}78.98 \\
\text { Very } \\
\text { Good }\end{array}$ & $\begin{array}{l}69.46 \\
\text { Good }\end{array}$ & $\begin{array}{c}34.263 \\
\text { Good }\end{array}$ \\
\hline \multirow{2}{*}{ DIV-2 } & $\begin{array}{l}\text { Tuffaceous } \\
\text { sandstone }\end{array}$ & $\begin{array}{l}75.59 \\
\text { Good }\end{array}$ & $\begin{array}{l}68.81 \\
\text { Good }\end{array}$ & $\begin{array}{c}32.484 \\
\text { Good }\end{array}$ \\
\hline & $\begin{array}{l}\text { Carbonate } \\
\text { interbeds }\end{array}$ & $\begin{array}{l}10.50 \\
\text { Very } \\
\text { Poor } \\
\end{array}$ & $\begin{array}{l}17.00 \\
\text { Very } \\
\text { Poor } \\
\end{array}$ & $\begin{array}{c}0.01 \\
\text { Exception } \\
\text { ally Poor }\end{array}$ \\
\hline \multirow{2}{*}{ DIV-3 } & $\begin{array}{l}\text { Tuffaceous } \\
\text { sandstone }\end{array}$ & $\begin{array}{l}66.74 \\
\text { Good }\end{array}$ & $\begin{array}{l}67.69 \\
\text { Good }\end{array}$ & $\begin{array}{c}28.306 \\
\text { Good }\end{array}$ \\
\hline & $\begin{array}{l}\text { Carbonate } \\
\text { interbeds }\end{array}$ & $\begin{array}{l}36.97 \\
\text { Poor }\end{array}$ & $\begin{array}{c}32.56 \\
\text { Poor }\end{array}$ & $\begin{array}{c}11.413 \\
\text { Good }\end{array}$ \\
\hline
\end{tabular}

\subsection{Correlation between GSI, RMR, dan Q- system}

The quality of the rock mass that is correlated is 153 points on the tuffaceous sandstone. There is no correlation for carbonate interbeds due to insufficient data and poor quality.

The correlation between GSI and RMR is shown in Figure 8 by comparing the results between the study areas with the Hoek and Brown (1997) [6], Ali et al. (2014) [7], and Zhang et al. (2019) [8]. Correlation is linear, where the correlation in the study area has a more vertical line. The relationship between GSI and RMR in the study area is stated in Equation 10 with a coefficient of determination of 0.6653 .

$$
G S I=2.2885 R M R-82.567\left(\mathrm{R}^{2}=0.6653\right)
$$

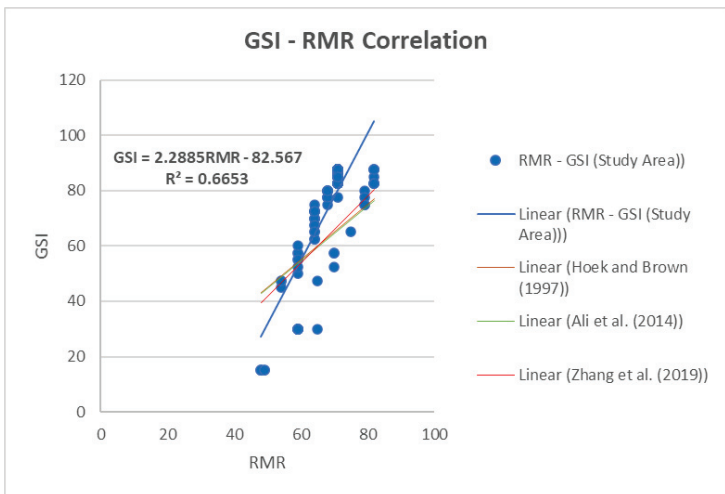

Fig. 8. GSI - RMR correlation graph.

The relationship between RMR and Q-system (Figure 9) shows a line of correlation the results in the study area with Bieniawski (1976) [9], Cameron-Clarke and Budavari (1981) [10], Vásárhelyi and Deák (2010) [11], and Laderian and Abaspoor (2012) [12]. The correlation line is in the form of the logarithm, with a coefficient of determination of 0.4987 . The correlation between RMR and Q-system in the study location is stated in Equation 11.

$$
R M R=2.0175 \ln (Q)+63.061\left(\mathrm{R}^{2}=0.4987\right)
$$

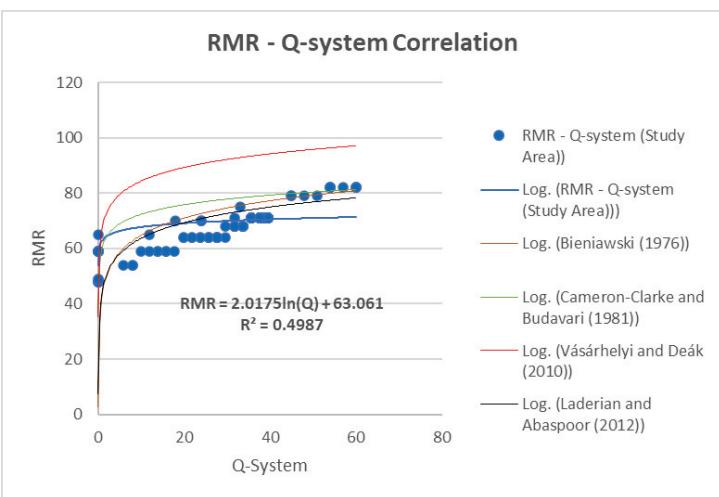

Fig. 9. RMR - Q-system correlation graph.

The relationship between GSI and Q-system is shown in the graph in Figure 10. Correlation is logarithmic, with a coefficient of determination of 
0.8095. The relationship between GSI and Q-system in the study area is stated in Equation 12 below.

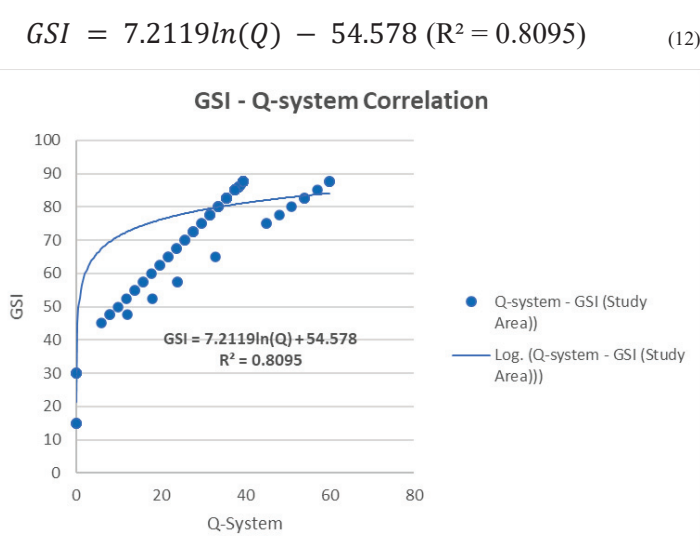

Fig. 10. GSI - Q-system correlation graph.

\section{Conclusion and recommendation}

The research area is in the Tiga Dihaji Dam's diversion tunnel, with a tunnel length of $595 \mathrm{~m}$. The geological conditions in the research area consist of tuffaceous sandstone and carbonate interbeds. The results of the rock mass quality analysis show that the value of tuffaceous sandstone had a GSI value of 15 - 87.5 (very poor - very good), RMR 48 - 82 (fair - very good), and Q-system $0.01-60.0$ (exceptionally poor - very good). Meanwhile, carbonate interbeds have a low value, with a GSI value of 10.5 - 77.5 (very poor to very good), RMR 17.0 - 56.0 (very poor - fair), and Q-system 0.01 - 35.2 (exceptionally poor - good). From these results, the values of rock mass strength, especially tuffaceous sandstone, were correlated in this study, namely GSI RMR, RMR - Q-system, and GSI - Q-system. The correlation between GSI and RMR is obtained by the equation GSI $=2.2885 \mathrm{RMR}-82.567\left(\mathrm{R}^{2}=0.6653\right)$, $\mathrm{RMR}$ and Q-system RMR $=2.0175 \ln (\mathrm{Q})+63.061\left(\mathrm{R}^{2}\right.$ $=0.4987)$, and GSI and Q-system GSI $=7.2119 \ln (\mathrm{Q})$ $54.578\left(\mathrm{R}^{2}=0.8095\right)$. This equation will be more accurate if more sample points are analyzed.

It is recommended that further studies be undertaken in the following area: the stability of the tunnel by using a numerical method with the input of reinforcement parameters based on the rock mass that has been obtained.

Thanks to the River Basin Organization (BBWS in Indonesian) in Sumatera VIII for allowing the study at the Tiga Haji Dam, and Mr. I Gde Budi Indrawan for guidance during data collection in the study area.

\section{References}

1. PT Virama Karya, Detail engineering design Bendungan Tiga Dihaji, (PT Virama Karya, Palembang, 2016)
2. M. Sharifzadeh, F. Kolivand, M. Ghorbani, S. Yasrobi, Tunneling \& Underground Space Tech. 35, 178-188 (2013)

3. Z. T. Bieniawski, Engineering rock mass classifications: a complete manual for engineers and geologists in mining, civil and petroleum engineering, (A Wiley-Interscience Publication, New York, 1989)

4. E. Hoek, T. G. Carter, M. S. Diederichs, Quantification of the geological strength index chart, in Proceedings of the 47th US Rock Mechanics/Geomechanics, Symposium San Francisco, 23-26 June 2013, USA (2013)

5. N. Barton, R. Lien, J. Lunde, Springer-Verlag 6, 4:189-236 (1974)

6. E. Hoek, E. T. Brown, Inter. J. of Rock Mechanics \& Mining Sci. 34, 8:1165-1186 (1997)

7. W. Ali, N. Muhammad, M. Tahir, Inter. J. of Sci. Eng. \& Tech. 3, 1292-1296 (2014)

8. Q. Zhang, X. Huang, H. Zhu, J. Lia, Tunnelling and Underground Space Tech. 83, 73-81 (2019)

9. Z. T. Bieniawski, Rock mass classification in rock engineering, in Proceedings Symposium Exploration Rock Engineering, Johannesburg, 97106 (1976)

10. I. S. Cameron-Clarke, S. Budavari, Engineering Geology 17, 19-53 (1981)

11. B. Vásárhelyi, F. Deák, Comparing the different Rock Mass Classifications on the Access Tunnels of Bátaapáti, Hungary, in Conference: Geologically Active, 3773-3780 (2010)

12. A. Laderian, M. A. Abaspoor, Tunneling and underground space tech. 27, 149-158 (2012)

13. D. U. Deere, Rock Mechanics and Eng. Geology 1,16-22 (1963)

14. S. Gafoer, T. C. Amin, R. Pardede, Peta geologi lembar Baturaja, Sumatera (Pusat Pengembangan dan Penelitian Geologi, Bandung, 1993) 